\title{
Verzeichnis der wichtigsten Symbole
}

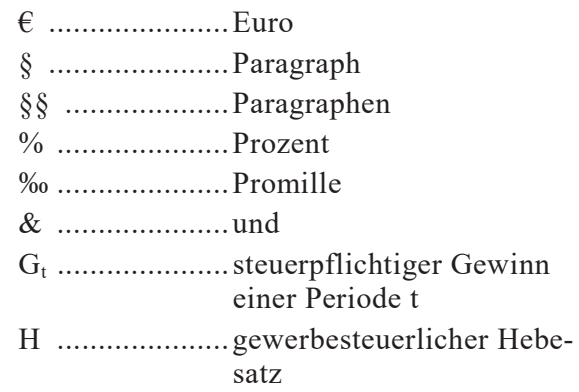

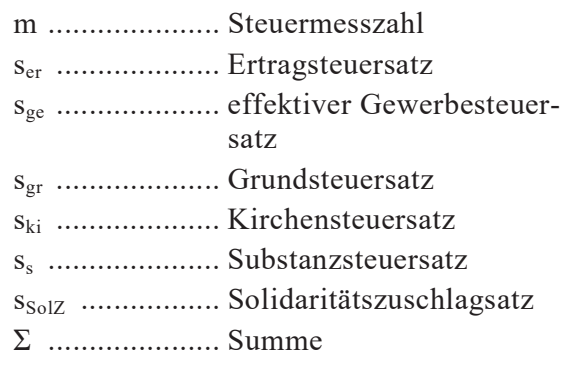


